\title{
Evaluation of the Salicylic Acid-Liquid Phase Scrubbing Technique to Monitor Atmospheric Hydroxyl Radicals
}

\author{
R. A. SALMON ${ }^{1,2}$, C. L. SCHILLER ${ }^{1}$ and G. W. HARRIS ${ }^{1}$
}

\begin{abstract}
A novel method has been examined for monitoring tropospheric hydroxyl radicals $(\mathrm{OH})$, the most important oxidant in tropospheric chemistry. Aqueous phase salicylic acid reacts with atmospheric $\mathrm{OH}$ to produce 2,5-dihydroxy benzoic acid (2,5-DHBA) and other products. High Performance Liquid Chromatography (HPLC) is used to separate the post-reaction solution and the products are quantified using fluorescence detection. Unlike other methods, it has been reported to be inexpensive, portable and relatively simple. Although the sensitivity was sufficient to measure typical daytime $\mathrm{OH}$ concentrations of $0.04-0.4$ ppt., the method was hindered by numerous interferences. Successive identification and elimination of these still resulted in a signal that was much larger than expected. Tests showed that this was not likely to be due to ozone, $\mathrm{HO}_{2}, \mathrm{NOx}, \mathrm{H}_{2} \mathrm{O}_{2}$, aerosols, light or bacteria. Experimental and numerical studies suggest that the interference could be due to methyl peroxy radicals. The effect of many other components in the atmosphere, both individual and combined, must also be tested before the method can be used reliably in the field. The validity of previous reports of ambient hydroxyl measurements using this technique is therefore brought into question.
\end{abstract}

Key words: ambient data, hydroxyl radical, interference test, $\mathrm{OH}$, salicylic acid

\section{Introduction}

The hydroxyl radical, although crucial in tropospheric oxidation processes, has very low atmospheric concentrations $\left(\sim 0.04 \mathrm{ppt}, 10^{6}\right.$ molecules $\left.\mathrm{cm}^{-3}\right)$. Tropospheric $\mathrm{OH}$ is produced primarily by the photolysis of ozone injected from the stratosphere or formed photochemically via processes involving NO $x$ and hydrocarbons. During low light conditions when ozone photolysis is minimal, the oxidation of alkenes by ozone (Fenske et al., 2000 and references therein) and the photolysis of nitrous acid (Harris et al., 1982; Schiller et al., 2001) may also become significant HO $x$ sources in the polluted troposphere. The hydroxyl radical reacts rapidly with a vast number of atmospheric species resulting in $\mathrm{OH}$ having a very short lifetime $(0.2$ to $1 \mathrm{sec})$ and therefore highly localised concentrations, both spatially and temporally. 
There are currently five reported methods with high selectivity and sensitivity required for measurement of $\mathrm{OH}$ at atmospheric concentrations. Fluorescence Assay by Gas Expansion, FAGE, and Differential Optical Absorption Spectroscopy, DOAS, are optical methods that provide virtually instantaneous hydroxyl radical concentrations (Hard et al., 1984; Brune et al., 1995; Crosley, 1995; Dorn and Hofzumahaus, 2000, and references therein). These systems are, however, very expensive and relatively cumbersome compared with indirect chemical tracer methods. Chem-ionisation mass spectrometry (CI-MS) (Eisele and Tanner, 1991, Eisele, 1995), the radiocarbon method (Felton et al., 1990, Campbell et al., 1995) and salicylic acid method (Chen and Mopper, 2000, Ren et al., 2000) are chemical tracer methods that involve the conversion of $\mathrm{OH}$ into a more easily measured species. These generally involve the reaction of $\mathrm{OH}$ with some species for a time period that is long enough to produce a significant build-up or depletion of a tracer compound. The monitoring time is, therefore, long compared to the lifetime of $\mathrm{OH}, \tau_{\mathrm{OH}}$, except for CI-MS that uses chemical reactions that are fast relative to $\tau_{\mathrm{OH}}$ (Eisele and Tanner, 1991).

The measurement of aqueous $\mathrm{OH}$ concentrations using salicylic acid as a tracer in biological systems is well established (e.g. Grootveld and Halliwell, 1986; Das et al., 1991; Blandini et al., 1999; McCabe et al., 1997; Owen et al. 1996 and references therein). Application of this method to atmospheric gas phase $\mathrm{OH}$, however, is relatively new and has been studied at Washington State University, (Chen, 1995; Chen and Mopper, 2000), Peking University (Ren et al., 2000, 2001, 2002), the Max-Planck-Institüt, Mainz (E. Oberlander, private communication) and York University, Toronto (this work).

The chemical reaction central to the salicylic acid method is shown in Figure 1. It is generally accepted that the mechanism occurs via a hydroxycyclohexadienyl

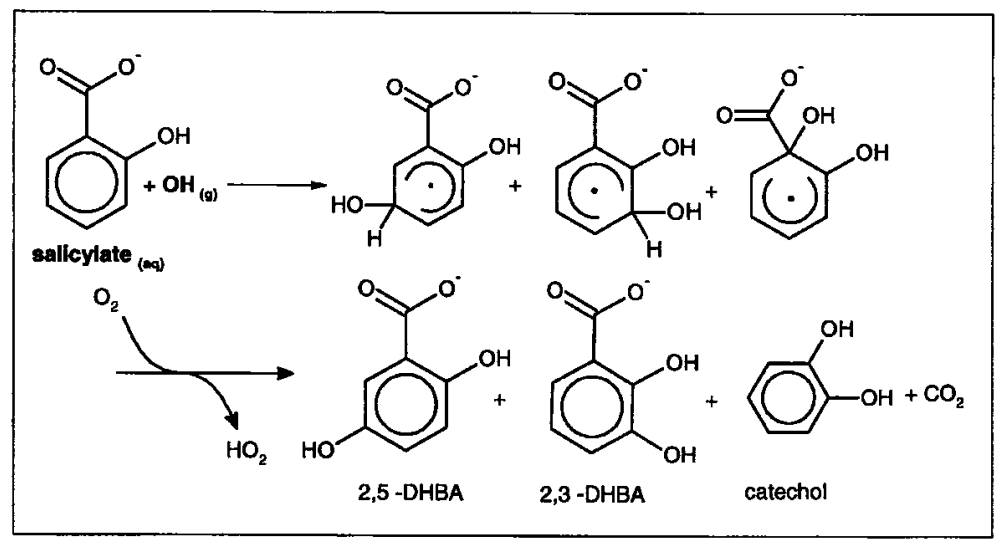

Figure 1. Oxidation mechanism of salicylic acid. 
radical intermediate (Lang et al., 1996). Due to ring activation, the positions orthoand para- to the hydroxy substituent are much more readily oxidised than the meta isomer (Buxton et al., 1986). Following hydroxylation, dissolved oxygen abstracts hydrogen from the intermediate releasing $\mathrm{HO}_{2}$ and a range of oxidation products. Among these, 2,5-dihydroxy benzoic acid (2,5-DHBA), 2,3-dihydroxy benzoic acid (2,3-DHBA) and catechol are produced in the highest yield and are therefore used as tracers for $\mathrm{OH}$. Since 2,5-DHBA is a known product during the microbial metabolism of salicylic acid, the biological research community prefers the monitoring of the 2,3-DHBA isomer (Halliwell et al., 1991; Ingelman-Sundberg et al., 1991; Dupont et al., 1999, Strolin-Benedetti, 1999). However, the 2,5-DHBA exhibits a considerably stronger fluorescence than the 2,3-DHBA and since microbial metabolism can be minimised when monitoring atmospheric $\mathrm{OH}$, it became the species of choice for atmospheric $\mathrm{OH}$ measurements. Sampling is straightforward, with ambient air bubbled through a solution containing salicylic acid for approximately $30 \mathrm{~min}$. Salicylic acid and the reaction products are separated using HPLC followed by fluorescence detection. The original gaseous hydroxyl radical concentration is directly proportional to the concentration of 2,5-DHBA and can be calculated using knowledge of the product yield and sampling efficiency. Preliminary investigations into this technique reported successful quantification of ambient $\mathrm{OH}$ (Chen, 1995) and an impressive detection limit of $3-6 \times 10^{5} \mathrm{OH} \mathrm{cm}^{-3}$ with an integration time of 45-90 min (Chen and Mopper, 2000).

The simplicity and sensitivity of the chemical tracer method involving 2,5DHBA makes it attractive for adaptation to routine air monitoring. Frequent measurement of $\mathrm{OH}$ in parallel with the measurement of other atmospheric species at a wide variety of locations could expand our understanding of processes occurring in tropospheric chemistry. The aim of this research was to assess the viability of the salicylic acid tracer method for monitoring atmospheric hydroxyl radicals.

\section{Experimental}

\subsection{CHEMICALS, PREPARATION AND HANDLING}

Research grade chemicals, including $\mathrm{NaH}_{2} \mathrm{PO}_{4}, \mathrm{Na}_{2} \mathrm{HPO}_{4}$, salicylic acid (>98\% purity), 2,3- and 2,5- dihydroxy benzoic acids and $\mathrm{KI}$ were obtained from SigmaAldrich (Milwaukee, WI, USA). Salicylic acid and 2,5-DHBA were required in purities greater than could be purchased, so additional purification was necessary. Recrystalisation was carried out at least twice under nitrogen and red-light conditions. Once purified, crystalline salicylic acid and 2,5-DHBA were stored below $0^{\circ} \mathrm{C}$ under oxygen free conditions, thus maintaining their purity for about 1 year.

Salicylic acid and its oxidation products are light sensitive. This required that all experiments were carried out under complete red-light conditions and reaction chambers were designed to minimise the exposure of the solutions to light. This was found to remove the light interference completely. 
Among biology researchers, it is accepted that 2,5-DHBA is a less reliable tracer for $\mathrm{OH}$ than the 2,3- isomer since it is an enzymatic metabolite of salicylic acid (Halliwell et al., 1991; Ingelman-Sundberg et al., 1991; Dupont et al., 1999; Strolin-Benedetti, 1999). 2,3-DHBA is therefore the tracer of choice for biological applications since a micromolar detection limit is usually sufficient. For our application, bacterial growth could be minimised by sparging the reaction solutions with an inert gas to purge oxygen from the system and by refrigeration. This resulted in stable solutions with no noticeable 2,5-DHBA production for weeks under storage conditions.

With product concentrations in the picomolar region, careful handling and preparation of glassware and solutions was essential. No metal was allowed in contact with the salicylic acid or its oxidation products. Before and after sampling, solutions were kept under oxygen free conditions and if not immediately in use, stored between $0^{\circ} \mathrm{C}$ and $4^{\circ} \mathrm{C}$. Sonication to aid dissolution was found to exacerbate oxidation of salicylic acid in-situ and thus avoided. Reactive oxygen is probably formed during sonolysis (Weavers et al., 1998; Blandini et al., 1999). The extraction process employed by Ren et al. (2000) for dissolving reacted salicylic acid from an impregnated filter utilised sonication and thus may have produced some of the 2,5-DHBA detected in the extracted solution.

\subsection{SAMPLING AND ANALYSIS}

A sampling solution consisting of $9 \times 10^{-6} \mathrm{M}$ salicylic acid in $50 \mathrm{mM}$ phosphate buffer at $\mathrm{pH} 4.6$ was used to scrub gas phase $\mathrm{OH}$. Ambient air was drawn through a reaction vessel containing the salicylic acid solution for approximately $30 \mathrm{~min}$, quantitatively removing $\mathrm{OH}$ from the air stream. The reaction vessel was designed to maximise the scrubbing efficiency and to minimise loss of $\mathrm{OH}$ on inlets and walls prior to reaction. Moreover, the chamber needed to be easy to clean and allow direct access to the solution for sparging and solution extraction. The resultant vessel design, shown in Figure 2, was able to address all of the above concerns and minimise sampling of species less soluble than $\mathrm{OH}$. The 'aerosol pipe' shown in this diagram is discussed later.

Sampling of ambient air in the absence of $\mathrm{OH}$ is critical for examining interferences. Blanks were sampled by utilising the high wall loss rate for $\mathrm{OH}$ to remove it from the sample air stream. Since there is little quantitative information about the wall loss rate of $\mathrm{OH}$ on $1 / 4^{\prime \prime}$ Teflon tubing at ambient pressure, the value for $\mathrm{HO}_{2}, 2.8 \mathrm{~s}^{-1}$ (Mihele et al., 1999), was used as a lower limit. A $4 \mathrm{~m} \times 0.625 \mathrm{~cm}$ OD teflon tube was added to the sample inlet, with the tube length chosen to be sufficient to remove all $\mathrm{HO}_{2}$ and $\mathrm{OH}$. The long inlet should only minimally perturb less reactive species, such as ozone.

The analytical configuration used for HPLC analysis incorporated parallel analysis of two samples, allowing for rapid air and blank analysis. A 90:10 filtered phosphate buffer ( $\mathrm{pH} \mathrm{6,50} \mathrm{mM):} \mathrm{methanol} \mathrm{(HPLC} \mathrm{grade,} \mathrm{Caledon} \mathrm{Laboratories,}$ 

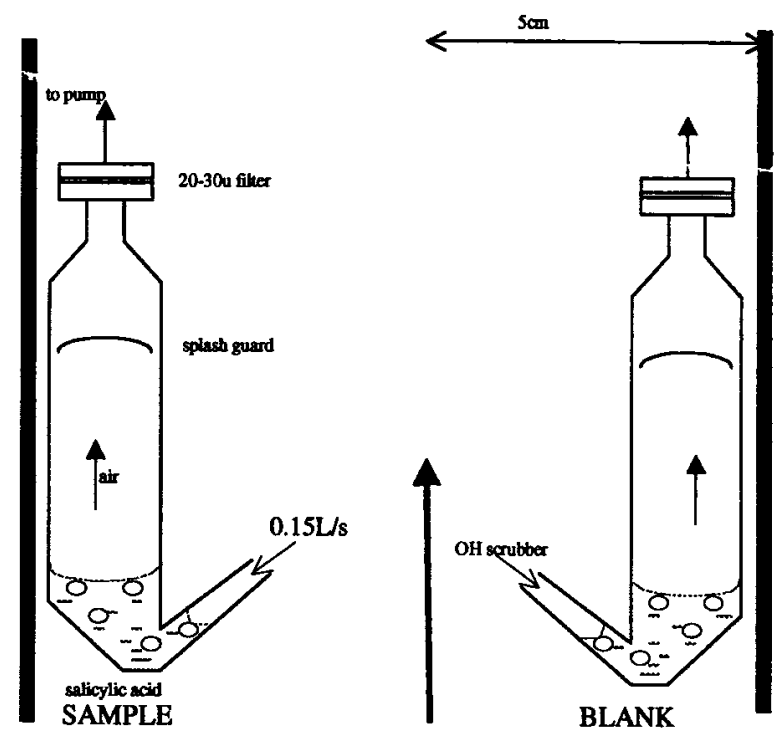

$80 \mathrm{~L} / \mathrm{s}$

Figure 2. Aqueous phase scrubber for quantitative $\mathrm{OH}$ collection. An 'acrosol pipe' designed to prevent particles being sampled through the reaction solution is included, which flows through the pipe approximately $80 \mathrm{Ls}^{-1}$ while the sampling flow was $\sim 9 \mathrm{Lmin}^{-1}$.

Georgetown, ON, Canada) eluent was delivered through two parallel solvent delivery systems (Varian Star 9010, and Waters 510) coupled with reverse phase C-18 pre- and post-analytical columns (Chromatography Sciences Co., Montreal, QC, Canada). Automated injection using a $100 \mu \mathrm{L}$ sample loop and column switching was achieved using Rheodyne Lab-pro 6-port and 10-port electric actuated valves and a Valco VICI electric actuated 6-port valve. A broad-band CMA/280 detector and a tunable Jasco FP-920 fluorescence detector were coupled with BORWIN software for data acquisition and analysis. The Jasco FP-920 was optimised for 2,5DHBA at excitation and emission wavelengths of 314 and $439 \mathrm{~nm}$, respectively. The sensitivity of this analytical technique is illustrated in Figure 3 which shows a signal from $6.4 \times 10^{-10} \mathrm{M} 2,5$-DHBA, corresponding to approximately $1.0 \times 10^{7}$ $\mathrm{OH} \mathrm{cm} \mathrm{cm}^{-3}$ for our sampling conditions.

Calibration curves determined from standard solutions of salicylic acid, 2,3and 2,5-DHBA remained linear across the complete detection range of both detectors used. For 30 2,5-DHBA calibration curves obtained between March 1999 and January 2001, the mean correlation coefficient, $R^{2}>0.999$ and mean percentage error $<4 \%$. The instrumental detection limit $(S / N=3)$ was $45 \mathrm{pM}$, an order of magnitude lower than previous reports (e.g. Coudray et al., 1995; Diez et al., 2001; Jen et al., 1998; McCabe et al., 1997; Ren et al., 2001; Tsai et al., 1999; Yoshimura et al., 1989) with the exception of Chen and Mopper (2000). This detection limit 


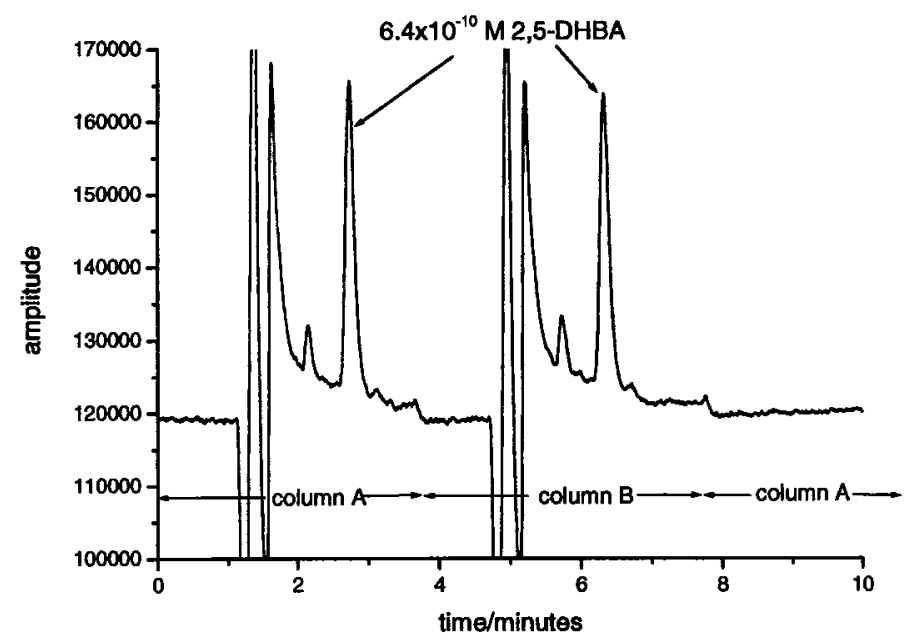

Figure 3. Chromatogram illustrating the sensitivity towards 2,5-DHBA during the SONTAS campaign, June 2000 . Signal is equivalent to $1 \times 10^{7}$ molecules $\mathrm{cm}^{-3}$ of $\mathrm{OH}$.

corresponds to $\mathrm{OH}$ concentrations of $9 \times 10^{5} \mathrm{OH} \mathrm{cm}^{-3}$ for a 30 min sampling period at $10 \mathrm{slm}$. This was similar to the detection limit determined from the standard deviation of the blank.

$$
D_{\mathrm{L}}=3 \sigma_{\text {blank }}=47 \mathrm{pM}
$$

Ambient $\mathrm{OH}$ concentrations (molecules $\mathrm{cm}^{-3}$ ) are calculated from the 2,5DHBA concentration (moles $\mathrm{L}^{-1}$ ) by using equation $\mathrm{E} 2$ in which $V_{\mathrm{f}}(\mathrm{L})$ is the post-reaction volume of salicylic acid, $F(\mathrm{slm})$ is the air flow rate through the sampler, $t$ is the sampling time in minutes and $B$ is the branching ratio, or product yield, of 2,5-DHBA at the sampling $\mathrm{pH}$ discussed further in Section 3.2.

$$
[\mathrm{OH}]=\frac{[2,5-\mathrm{DHBA}] V_{\mathrm{f}} N_{\mathrm{A}}}{1000 \text { FtB }}
$$

Due to the evaporation of water during sampling and post-reaction sparging, the sample volume typically reduces to $2-3 \mathrm{ml}$ from an initial volume of $4 \mathrm{ml}$. Since the final volume is critical in determining the concentration, the final volume must be accurately determined prior to HPLC analysis. Since less than $0.1 \%$ of salicylic acid is oxidised during the reaction, any change in the concentration of salicylic acid measured is due to the change in the volume. Therefore the post reaction solution volume, $V_{\mathrm{f}}$, can be calculated using $\mathrm{E} 3$ in which $[\mathrm{SAL}]_{\mathrm{i}}$ and $[\mathrm{SAL}]_{\mathrm{f}}$, the initial and final concentrations of salicylic acid, are determined by HPLC and fluorescence detection and $V_{\mathrm{i}}$ is the initial sample volume. This has the added advantage of minimising additional handling errors and possibilities for contamination that may 
occur if the final volume was measured rather than calculated.

$$
V_{\mathrm{f}}=V_{\mathrm{i}}^{*}\left([\mathrm{SAL}]_{\mathrm{i}} /[\mathrm{SAL}]_{\mathrm{f}}\right)
$$

\subsection{LABORATORY OH SOURCES}

Initial laboratory tests required a synthetic source of gaseous $\mathrm{OH}$. Hydroxyl radicals were produced via simultaneous photolysis of water vapour and oxygen at $185 \mathrm{~nm}$ to produce $\mathrm{OH}, \mathrm{HO}_{2}$ and ozone (Schultz et al., 1995). A constant flow of humidified synthetic air was passed through a $60 \mathrm{~cm}$ long, $2.7 \mathrm{~cm}$ diameter quartz flow tube and irradiated at $184.9 \mathrm{~nm}$ with a Pen-Ray $11 \mathrm{SC}-2$ mercury lamp (UVP Inc., Upland, CA). The total flow rate was $13-15 \mathrm{Lmin}^{-1}$ and water mixing ratios ranged from $6 \times 10^{-5}$ to $1.0 \times 10^{-3}$. The $\mathrm{OH}$ concentration was calculated using the knowledge of the concentrations and absorption cross sections of water and ozone as discussed in detail elsewhere (Schultz et al., 1995; Creasey et al., 2000; Lanzendorf et al., 1997; Hofzumahaus et al., 1997).

$$
[\mathrm{OH}]=\frac{1}{2} \frac{\left[\mathrm{O}_{3}\right]\left[\mathrm{H}_{2} \mathrm{O}\right] \sigma_{185 \mathrm{~nm}\left(\mathrm{H}_{2} \mathrm{O}\right)}}{\left[\mathrm{O}_{2}\right] \sigma_{185 \mathrm{~nm}\left(\mathrm{O}_{2}\right)}}
$$

Oxygen mixing ratios in the gas flow were calculated while water and $\mathrm{O}_{3}$ concentrations were measured using an EG\&G Model 911 'Dew All' Digital Humidity Analyser and a Thermo-Environmental Instruments ozone analyser, respectively.

Determination of the branching ratio for the production of 2,5-DHBA in the reaction of $\mathrm{OH}$ with salicylic acid required the use of a liquid phase $\mathrm{OH}$ source. Liquid phase $\mathrm{OH}$ was produced by the photolysis of $\mathrm{H}_{2} \mathrm{O}_{2}$ in solution. An apparatus was designed containing a $3 \mathrm{~mm}$ thick IR-grade fused silica window situated between a Pen-Ray 11SC-2 mercury lamp (UVP Inc., Upland, CA) and quartz cuvette (McCarthy, UK) containing the aerated reaction solution. This allowed light at 254 $\mathrm{nm}$ to photolyse $\mathrm{H}_{2} \mathrm{O}_{2}$ while blocking the $184.9 \mathrm{~nm}$ line which photolysis water. In order to avoid ozone production, the apparatus was flushed with nitrogen.

\section{Results and Discussion}

\subsection{LINEAR RESPONSE TO GAS PHASE OH}

The response of the instrument to gas phase $[\mathrm{OH}]$ was determined over a range of water vapor concentrations. Due to a potential interference from ozone, which is also produced in the gas phase $\mathrm{OH}$ source, $\mathrm{KI}$ was added to the reaction solution as a chemical scrubber. Further, to minimise $\mathrm{O}_{3}$ production, only enough oxygen $(0.5-$ $5 \%$ ) was present in the gas flow to facilitate $\mathrm{H}$-abstraction from the cyclohexadienyl intermediate (and thus production of 2,5-DHBA). Under these conditions, accurate quantification of $\left[\mathrm{O}_{3}\right]$ and therefore $[\mathrm{OH}]$ was hindered, but the $[\mathrm{OH}]$ produced remains proportional to the $\left[\mathrm{H}_{2} \mathrm{O}\right]$ in the source. These experiments confirmed that the technique produced a signal that was proportional to $\mathrm{OH}$ (Figure 4). 


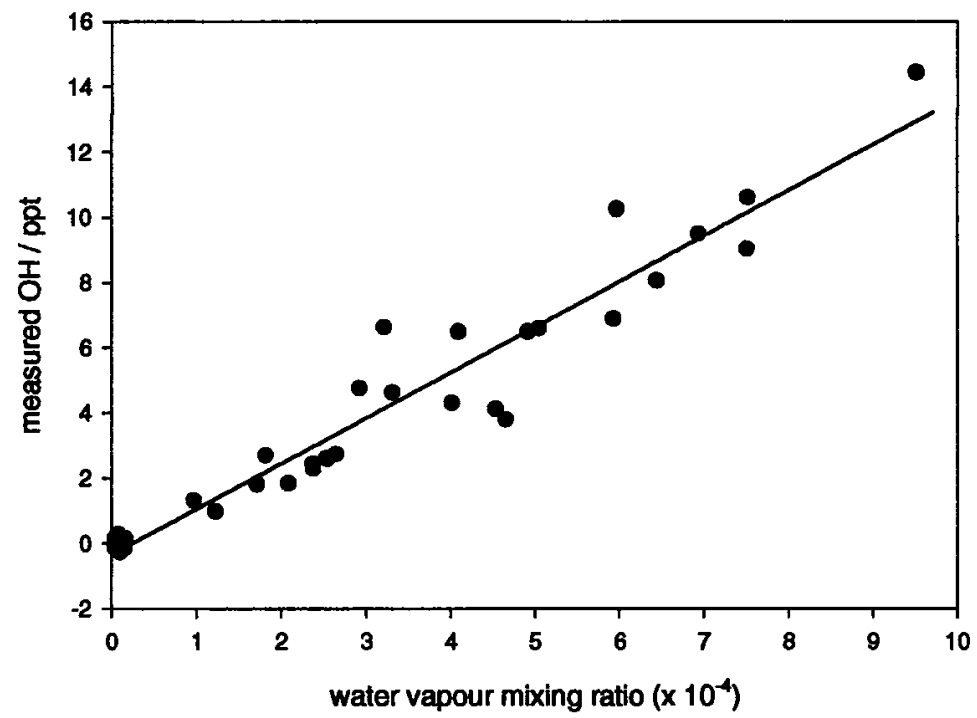

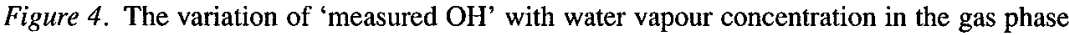
calibration system $\left(R^{2}=0.93\right)$. The magnitude of the mean ozone signal for a given experiment is set as the background value.

\subsection{YIELD OF 2,5-DHBA}

Knowledge of the branching ratio for 2,5-DHBA production following hydroxylation of salicylic acid is crucial for determination of hydroxyl concentrations (E2). A solution of $\sim 2.6 \times 10^{-4} \mathrm{M} \mathrm{H}_{2} \mathrm{O}_{2}$ (Aldrich Chemical Co., Milwaukee, WI) and $3 \times 10^{-7} \mathrm{M}$ salicylic acid was prepared in $50 \mathrm{mM}$ phosphate/phosphoric acid buffer at the required $\mathrm{pH}$. The sample was photolysed and the production of 2,5-DHBA monitored as a function of the $\mathrm{pH}$. Since the yield of 2,5-DHBA decreases considerably with $\mathrm{pH}$, photolysis times ranged from $45 \mathrm{~min}$ at $\mathrm{pH} 6$ to $170 \mathrm{~min}$ at $\mathrm{pH} 2.5$. Experiments confirmed that the loss of salicylic acid was proportional to photolysis time.

The branching ratio, or product yield, B, was calculated as the ratio of DHBA produced to salicylic acid lost (E5).

$$
B=\frac{[\mathrm{DHBA}] \int_{\text {produced }}}{[\text { total } \times \text { products }]}=\frac{[\mathrm{DHBA}] \int_{\text {produced }}}{[\text { Salicylic } \times \text { Acid }]_{\text {reacted }}}
$$

The product yield of 2,3- and 2,5-DHBA at $\mathrm{pH} 6$ remained constant over a range of photolysis times indicating that these products were not being further photolysed. Long photolysis times were required to decrease the uncertainty in the quantification of salicylic acid change, and only losses of greater than $4 \%$ were used. Figure 5 shows the effect of $\mathrm{pH}$ on 2,3- and 2,5-DHBA yield. The yield of 2,5-DHBA was found to increase with $\mathrm{pH}$ to a maximum of $30 \%$ at $\mathrm{pH}$ values 

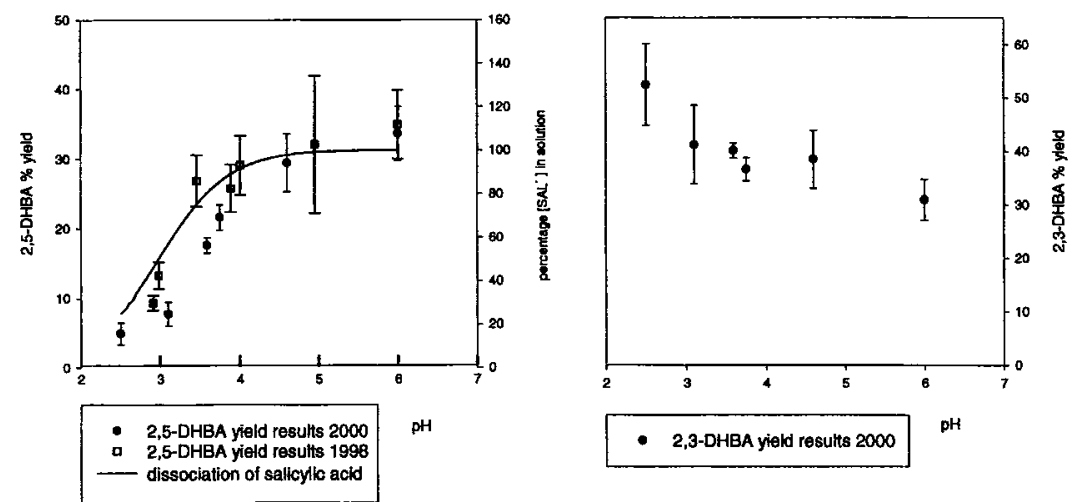

Figure 5. 2,5- and 2,3-DHBA aqueous phase yield as a function of $\mathrm{pH}$ and the corresponding percentage of salicylate ion in solution. Results from experiments carried out in 1998 and 2000 are marked separately.

above 4.5. This correlates with the degree of dissociation of salicylic acid, also shown in Figure 5. On the other hand, the 2,3-DHBA yields increased with acidity. These results are consistent with Lang et al. (1996) who stated, "the effect of pH on formation of hydroxylation products is more profound for 2,5-DHB than for 2,3$D H B$." The change in isomer ratio, [2,3-DHBA]:[2,5-DHBA], and absolute yield with $\mathrm{pH}$ is also consistent with trends observed by Jen et al. (1998) and Lang et al. $(1994,1996)$ although a direct comparison is not possible due to differences in experimental conditions.

The close correlation between 2,5-DHBA yield and the salicylate anion supports the theory that hydroxylation occurs via a hydroxycyclohexadienyl radical intermediate. Deprotonation of the acid group activates the ring, thus encouraging attack by $\mathrm{OH}$ radicals. Lang et al. (1996) found that the yield of 2,5-DHBA drops considerably below $\mathrm{pH} 4$ and suggested this is due to the lower reactivity of protonated salicylic acid $(p K a=2.97)$. With increasing $\mathrm{pH}$, the concentration of salicylate anion increases thereby increasing the reactivity of the solution towards $\mathrm{OH}$. It follows that an alternative mechanism may therefore be responsible for the production of 2,3-DHBA, especially under acidic conditions. The work by Ren et al. (2001) uses a 2,5-DHBA yield of $23 \%$ at $\mathrm{pH} 3.5$ (X. Ren, personal communication 2002), while Gokoren and Tunçel (1997) reported that " $33 \%$ of salicylate was changed into the hydroxylated form" following irradiation of a salicylic acid- $\mathrm{H}_{2} \mathrm{O}_{2}$ solution at $\mathrm{pH}$ 8.5. In contrast to these groups and our results, Chen (1995), Chen and Mopper (2000) report a linear dependence of the 2,5-DHBA yields on $\mathrm{pH}$, ranging between about $25 \%$ at $\mathrm{pH} 3$ to almost $100 \%$ at $\mathrm{pH} 7$ in an aerated solution. This study is the only study in claiming a $100 \%$ production of any one product at any $\mathrm{pH}$. The present result for the yield of 2,5-DHBA and its agreement with previously reported values other than Chen and Mopper (2000) brings the latters' result of $100 \%$ yield at $\mathrm{pH}=7$ into question. 


\subsection{INTERFERENCE INVESTIGATION}

Using 2,5-DHBA as a tracer, Chen and Mopper (2000), Ren (2000) and E. Oberlander (private communication, 1998), all report ambient $\mathrm{OH}$ concentrations higher than anticipated. Although the method has been the subject of a few preliminary investigations, no systematic laboratory study of potential atmospheric interferences has previously been reported. Ambient air sampling was used for all method optimisation experiments reported by Chen and Mopper (2000), with the exception of the aqueous phase yield determination described above. The majority of experiments were carried out at a polluted site. Given that the reported ambient measurements were much higher than expected and that only limited interference tests were carried out, we judged it to be important to test how the system reacts to various other species that are present in air. Therefore, laboratory interference tests for ozone, $\mathrm{NO}, \mathrm{NO}_{2}, \mathrm{HONO}$, hydrogen peroxide, $\mathrm{HO}_{2}, \mathrm{PAN}$ and $\mathrm{RO}_{2}$ were carried out.

\subsubsection{Ozone}

Ozone is a strong oxidant and is typically found in the atmosphere at concentrations that are 5-6 orders of magnitude larger than $\mathrm{OH}$. Therefore, even a relatively low reactivity towards salicylic acid could produce a large interference. Chen (1995) reports that the interference due to ozone is negligible in clean air and can be suppressed by addition of iodide in polluted air. However, our results indicated significant ozone interference even at relatively low concentrations of ozone $(<40 \mathrm{ppb})$.

Aqueous ozone chemistry and its interactions with organic compounds have been studied extensively in a variety of systems (e.g. Buehler et al., 1984; Gonzalez et al., 1997; Ko et al., 2000; Magi et al., 1997; Mokrini et al., 1997; Munoz et al., 2000, 2001; Spanggord et al., 2000; Staehlin and Hoigne, 1982; Staehlin et al., 1984; Weavers et al., 1998). The complexity of aqueous phase ozonation is revealed by decomposition rate laws that vary between $1 / 2,1$ st and 2 nd order in ozone depending on the initiation rate and water purity (Staehlin and Hoigne, 1985). It is, however, generally accepted that ozone interacts with organic solutes via both direct reaction and a radical chain process that ultimately produces $\mathrm{OH}$.

To study the effect of ozone on the production of 2,5-DHBA, the gas phase calibration source was used with air in the absence of water vapour. Only ozone was produced and the magnitude of the interference was determined as femtomoles of 2,5-DHBA produced per litre of air sampled. In the absence of interferences, a gaseous concentration of $2 \times 10^{6} \mathrm{OH} \mathrm{cm}{ }^{-3}$ would produce a 2,5-DHBA signal equivalent to $1 \mathrm{fmole} / \mathrm{L}_{\text {air }}$.

Figure 6 shows that the ozone interference is dependent on ozone concentration in a nonlinear fashion up to ozone mixing ratios around $60 \mathrm{ppb}$ and also depends on salicylic acid concentration. At higher ozone mixing ratios, aqueous phase processes probably limit the rate instead of mass transfer of ozone from the gas phase into solution. 


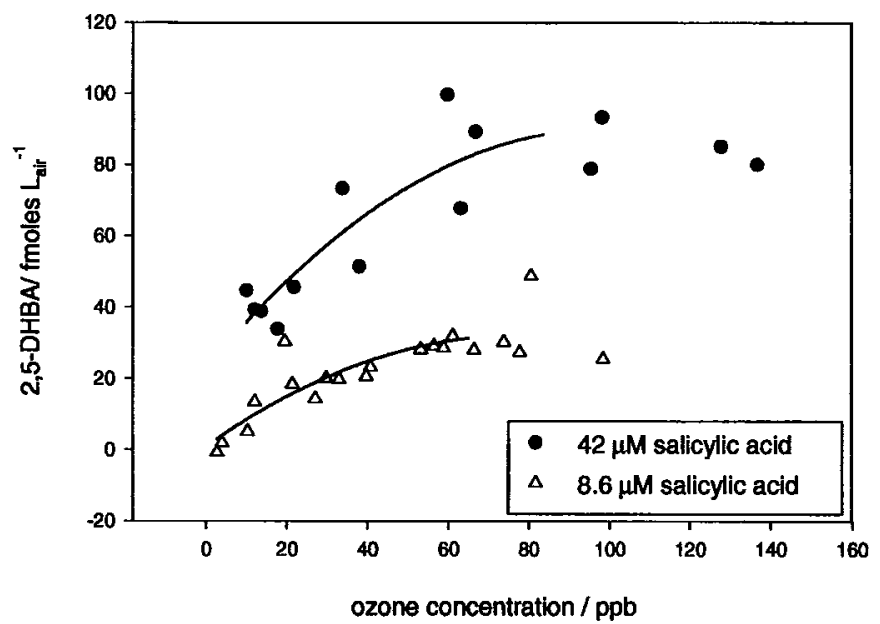

Figure 6. The interference due to ozone with gas phase ozone concentration at different salicylic acid concentrations and constant sampling $\mathrm{pH}$ of 4.6 .

The $\mathrm{pH}$ dependence of the 2,5-DHBA yield following reaction with ozone was also investigated. These results, presented together with the 2,5-DHBA yield following reaction with OH are shown in Figure 7. Mokrini et al. (1997) proposed that in neutral and basic solution, benzoic acid is oxidised by ozone via a free-radical pathway but in acidic solution direct attack by molecular ozone predominates. A sampling $\mathrm{pH}$ of 4.6 was chosen for further studies since this reduces the interference due to ozone while maintaining a high 2,5-DHBA yield following reaction with $\mathrm{OH}$.

Our experiments indicated an interference from typical ambient levels of ozone that could be up to two orders of magnitude larger than the expected $\mathrm{OH}$ signal. Chemical removal of solution phase ozone was therefore explored. An investigation into the potential scrubbing ability of iodide, sulphite and nitrite ions found KI to be the most reliable and reproducible chemical ozone scrubber since it neither reacts with salicylic acid or its oxidation products nor produce any chromatographic difficulties. Ozone dissolved in the reaction solution is scavenged by iodide according to R1.

$$
\mathrm{O}_{3}+3 \mathrm{I}^{-}+2 \mathrm{H}^{+} \rightarrow \mathrm{O}_{2}+\mathrm{I}_{3}^{-}+\mathrm{H}_{2} \mathrm{O}
$$

Figure 8 shows the removal of the direct ozone interference using KI. It can be seen that the signal due to ozone decreases linearly with iodide concentration until complete removal at 1-2 $\mu \mathrm{M} \mathrm{I}^{-}$. At this point, although the signal due to ozone alone has been removed, there is still a significant signal due to $\mathrm{OH}$. The magnitude of the ozone interference depends on mass transfer into solution as well as aqueous phase reactions. The low iodide concentration required to remove the 


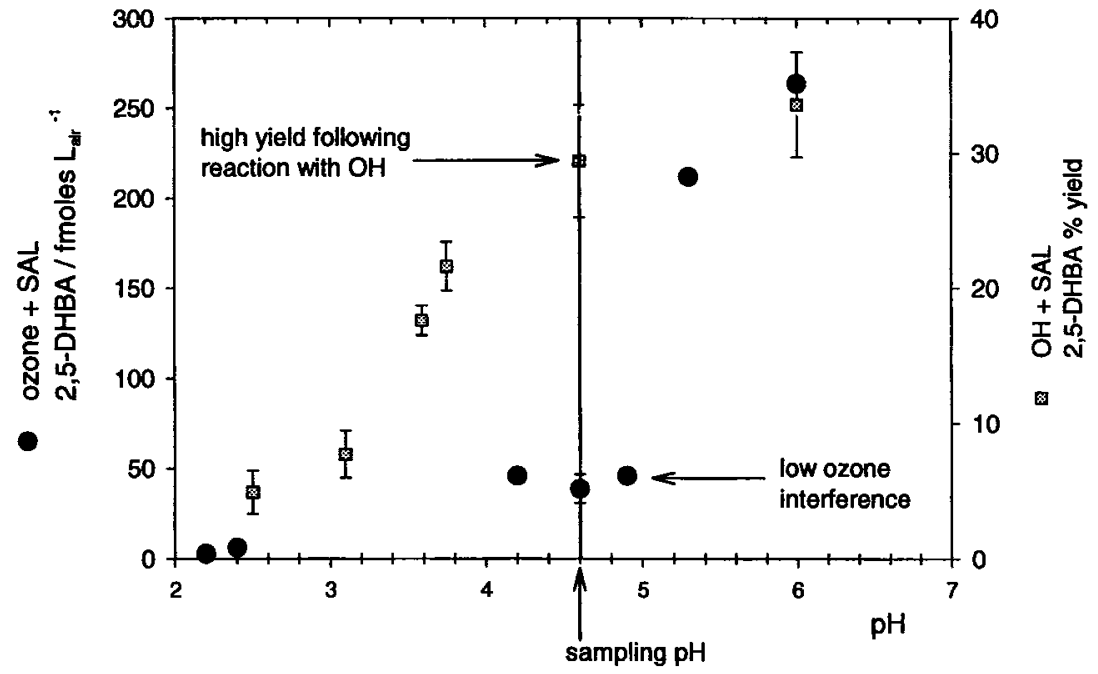

Figure 7. Effect of pH on the magnitude of the ozone interference (circles, left axis) and on the branching ratio to 2,5-DHBA following reaction between salicylic acid and $\mathrm{OH}$ (squares, right axis). The sampling $\mathrm{pH}$ of 4.6 minimise interferences while remaining at high yield after reaction with $\mathrm{OH}$.

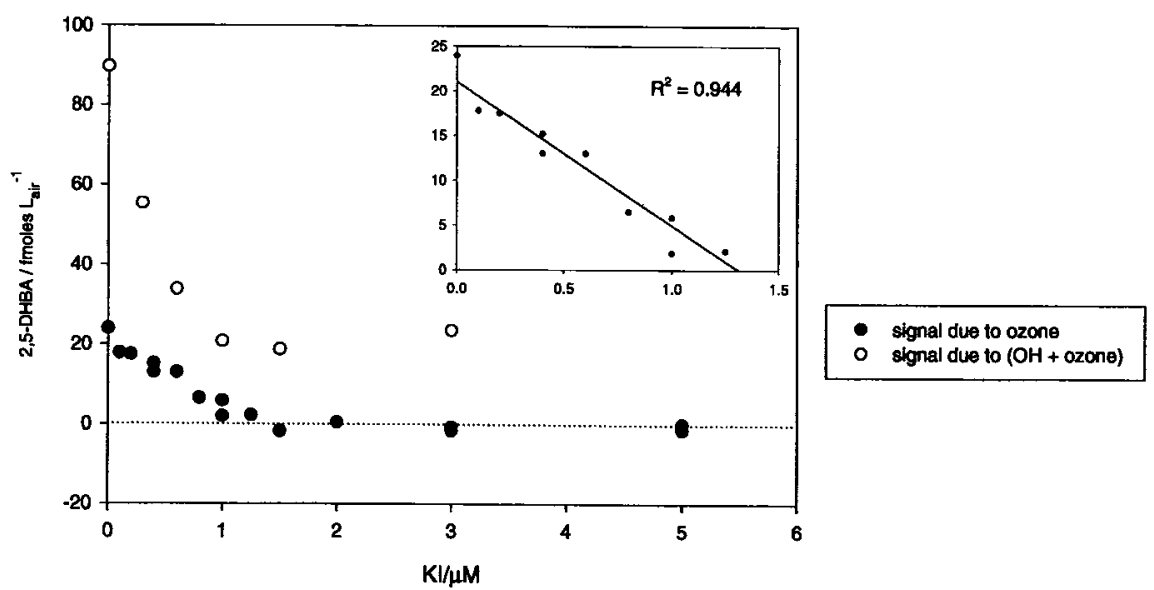

Figure 8. Effect of iodide concentration on the signal due to ozone and combined signal due to $\mathrm{OH}$ and ozone. Experimental conditions: $10 \mu \mathrm{M}$ salicylic acid, $45 \mathrm{ppb}$ ozone, $12 \mathrm{~min}$ sample time. Inset is linear portion of the variation in ozone signal with $\mathrm{KI}$. 
ozone interference relative to the ambient concentration of ozone suggests that only a very small fraction of gaseous ozone is actually destroyed in the sampler. The concentration of gaseous ozone, aqueous phase iodide and salicylic acid will, therefore, affect the magnitude of this signal. The decrease in ozone interference with KI was therefore also determined at different concentrations of ozone and salicylic acid with results suggesting that approximately $10 \mu \mathrm{M} \mathrm{KI}$ is sufficient to remove up to $80 \mathrm{ppb}$ ozone in $42 \mu \mathrm{M}$ salicylic acid (for further details, see Salmon 2002).

Although the interference due to ozone decreased linearly with iodide concentration, it can be seen in Figure 8 that the combined signal due to ozone and $\mathrm{OH}$ first decreased rapidly at low iodide concentration and then remained approximately constant. This suggests that there is an additional interference due to ozone that occurs only when hydroxyl radicals are also present. Was this not the case, the combined signal would be expected to decrease initially in parallel with the direct ozone interference. At higher iodide concentrations, the combined signal may then decrease slightly due to reaction between iodide and $\mathrm{OH}$. The substantial loss of net $\left(\mathrm{O}_{3}+\mathrm{OH}\right)$ signal on addition of low concentrations of iodide is indicative of production of 2,5-DHBA by ozone that is initiated by hydroxyl radicals. This $\left(\mathrm{O}_{3}+\mathrm{OH}\right)$ signal would not be detected by creating only $\mathrm{O}_{3}$ in the calibration system. Results from experiments investigating the effect of ozone in salicylic acid in the absence of radicals must therefore be treated with caution.

\subsection{2. $\mathrm{HONO}, \mathrm{NO}_{3} \mathrm{NO}$ and $\mathrm{NO}_{2}$}

The reactive odd nitrogen species ( $\mathrm{NO}, \mathrm{NO}_{2}, \mathrm{NO}_{3}$ and $\mathrm{HONO}$ ) are present at significant mixing ratios in the atmosphere and therefore their possible role in 2,5-DHBA production from salicylic acid was examined.

Testing these potential interferences involved the addition of large quantities of $\mathrm{NO}_{2}(10 \mathrm{ppm})$ and $\mathrm{NO}(100 \mathrm{ppb})$ individually, neither of which produced any 2,5DHBA. In addition, no signal was observed after sampling these high concentrations of $\mathrm{NO}_{2}$ in the presence of ozone suggesting that $\mathrm{NO}_{3}$ does not oxidise salicylic acid either. The addition of $10 \mu \mathrm{M} \mathrm{NaNO}_{2}$, to simulate the dissolution of HONO in solution failed to produce an increase in 2,5-DHBA. To qualitatively simulate possible HONO production and its subsequent photolysis within our blank inlet line, $1 \mathrm{ppm}$ of $\mathrm{NO}_{2}$ in humidified air was irradiated using a visible light source. No increase in the 2,5-DHBA was observed suggesting that neither HONO nor $\mathrm{OH}$ from the photolysis of HONO in the tubing produced interferences.

\subsection{3. $\mathrm{H}_{2} \mathrm{O}_{2}$ and Aerosols}

Ambient concentrations of hydrogen peroxide are typically a few parts per billion but have been measured as high as $40 \mathrm{ppb}$ (Seinfeld and Pandis, 1998) and direct oxidation of salicylic acid by $\mathrm{H}_{2} \mathrm{O}_{2}$ is possible. To simulate ambient conditions, 
pure air was bubbled through a $3 \% \mathrm{H}_{2} \mathrm{O}_{2}$ solution and sampled into $1 \times 10^{-6}$ $\mathrm{M}$ salicylic acid solution for $12 \mathrm{~min}$. The $17 \mathrm{ppb}$ of $\mathrm{H}_{2} \mathrm{O}_{2}$ produced, high for an expected ambient concentration, did not produce any 2,5-DHBA.

It is well known that iron can catalyse the reaction between salicylic acid and hydrogen peroxide via the Fenton reaction. Aerosols with diameter above $2.5 \mu \mathrm{m}$ contain the majority of crustal matter, which can contain significant amounts of iron. Aerosols could also promote interferences by providing a surface on which reactions with or producing $\mathrm{OH}$ can occur (Cooper and Abbatt, 1996). It is not viable to remove aerosols from the sampled air via a filter since this would almost certainly perturb $\mathrm{OH}$. A system was therefore developed that removed aerosols by using their inherent inertia. Figure 2 illustrates the sampling design used, in which air sampled by the reaction chamber is drawn at approximately $135^{\circ}$ from the bulk airflow. Idealised flow dynamics (Seinfeld and Pandis, 1998) predict that under our sampling conditions, aerosols with diameters greater than $3 \mu \mathrm{m}$ should be excluded (Salmon, 2002). This system also ensures that no light reaches the sampler, which was wrapped in black cloth inside the large pipe.

The possibility of iron entering the sampler was reduced, but could not be eliminated. However, as an additional safeguard against peroxide activity, $\mathrm{KI}$ added to the reaction solution will also catalytically destroy $\mathrm{H}_{2} \mathrm{O}_{2}$ (R2-R4).

$$
\begin{aligned}
& \mathrm{H}_{2} \mathrm{O}_{2}+\mathrm{I}^{-} \rightarrow \mathrm{IO}^{-}+\mathrm{H}_{2} \mathrm{O} \\
& \mathrm{IO}^{-}+\mathrm{H}_{2} \mathrm{O}_{2} \rightarrow \mathrm{I}^{-}+\mathrm{O}_{2}+\mathrm{H}_{2} \mathrm{O} \\
& 2 \mathrm{H}_{2} \mathrm{O}_{2} \rightarrow 2 \mathrm{H}_{2} \mathrm{O}+\mathrm{O}_{2}
\end{aligned}
$$

\subsection{4. $\mathrm{HO}_{2} / \mathrm{O}_{2}^{-}$}

The hydroperoxyl radical, $\mathrm{HO}_{2}$, found in the atmosphere in concentrations two orders of magnitude higher than $\mathrm{OH}$, may react directly with salicylic acid or as $\mathrm{O}_{2}^{-}$in an ozone initiated oxidation. The gas phase calibration system was used to produce $\mathrm{HO}_{2}, \mathrm{OH}$ and $\mathrm{O}_{3}$ and into this gas stream $100 \mathrm{ppm}$ of $\mathrm{CO}$ was added in order to convert all of the $\mathrm{OH}$ to $\mathrm{HO}_{2}$. The addition of $\mathrm{CO}$ effectively removed the 2,5-DHBA signal, indicating that neither $\mathrm{HO}_{2}$ nor $\mathrm{O}_{2}^{-}$was interferences at $\mathrm{pH}$ 4.6. A similar test by Ren et al. (2000) also concluded that $\mathrm{HO}_{2}$ was not an interference. Chen (1995) and Chen and Mopper (2000) mention the theoretical possibility of an $\mathrm{HO}_{2}$ interference but, like the ozone interference, make no mention of tests carried out to quantify or characterise it.

\subsection{5. $\mathrm{PAN}$ and $\mathrm{CH}_{3} \mathrm{CO} \cdot \mathrm{O}_{2}$}

Peroxyacetylnitrate, PAN, could also be a possible interference since it can thermally dissociate to form the peroxyacetyl radical. PAN is not readily photolysed in the troposphere, has a low solubility and its stability is strongly temperature 
dependent resulting in a highly variable ambient concentration from $<2$ ppt to 100 ppt or more (Seinfeld and Pandis, 1998). PAN was synthesised under laboratory conditions and sampled through salicylic acid to determine its potential as an interference.

Peroxyacetyl radicals and PAN were made in the laboratory from the photolysis of acetone in the presence of oxygen and subsequent reaction with $\mathrm{NO}_{2}$ as implemented by Meyrahn et al. (1987). Acetone was carried into a 1-L glass bulb by a stream of nitrogen at approximately $12 \mathrm{Lmin}^{-1}$. A Pen-Ray $11 \mathrm{SC}-2$ mercury lamp (UVP Inc., Upland, CA) was mounted inside the bulb, as close to the centre as possible. Synthetic air, necessary for salicylic acid to be oxidised to 2,5-DHBA, was introduced into the system either before or after the photolysis region. If air was present in the bulb, the acetone photolysis products quickly reacted with oxygen to produce $\mathrm{CH}_{3} \mathrm{O}_{2}$ and $\mathrm{CH}_{3} \mathrm{CO} . \mathrm{O}_{2}$ radicals. After leaving the bulb, the reaction mixture travelled down a coiled teflon tube before being sampled by salicylic acid. PAN was created if $\mathrm{NO}_{2}$ was added to $\mathrm{CH}_{3} \mathrm{CO} . \mathrm{O}_{2}$ radicals after they left the bulb.

$$
\begin{aligned}
& \mathrm{CH}_{3} \mathrm{C}(\mathrm{O}) \mathrm{CH}_{3}+\mathrm{h} \nu \rightarrow \mathrm{CH}_{3} \mathrm{C}(\mathrm{O})+\mathrm{CH}_{3} \\
& \mathrm{CH}_{3} \mathrm{C}(\mathrm{O})+\mathrm{O}_{2}+\mathrm{M} \rightarrow \mathrm{CH}_{3} \mathrm{C}(\mathrm{O}) \mathrm{O}_{2}+\mathrm{M} \\
& \mathrm{CH}_{3}+\mathrm{O}_{2} \rightarrow \mathrm{CH}_{3} \mathrm{O}_{2} \\
& \mathrm{CH}_{3} \mathrm{C}(\mathrm{O}) \mathrm{O}_{2}+\mathrm{NO}_{2}+\mathrm{M} \equiv \mathrm{CH}_{3} \mathrm{C}(\mathrm{O}) \mathrm{O}_{2} \cdot \mathrm{NO}_{2}+\mathrm{M}
\end{aligned}
$$

The results from this experiment are shown in Table I. Without photolysis only a small 2,5-DHBA signal was produced. When photolysis in the bulb occurred without acetone, ozone was produced resulting in a slightly higher signal, which was minimised by the addition of KI. Acetone photolysed in the presence of oxygen, produced $\mathrm{CH}_{3} \mathrm{C}(\mathrm{O}) \mathrm{O}_{2}$ and $\mathrm{CH}_{3} \mathrm{O}_{2}$ radicals that resulted in a large 2,5-DHBA signal. The addition of $\mathrm{NO}_{2}$ downstream of the photolysis bulb, resulted in a significant reduction of this signal. This suggests that although PAN itself does not oxidise salicylic acid, peroxy radicals could. These results could also be explained by the production of $\mathrm{OH}$ via $\mathrm{R} 9$ that has been recently reported by Blitz et al. (2002).

$$
\mathrm{CH}_{3} \mathrm{C}(\mathrm{O}) \mathrm{O}_{2}^{*}+\mathrm{M} \rightarrow \mathrm{HCHO}+\mathrm{CO}+\mathrm{OH}
$$

\subsection{6. $\mathrm{CH}_{3} \mathrm{O}_{2}$}

The above experiment indicated that an interference from methyl peroxy radicals $\left(\mathrm{CH}_{3} \mathrm{O}_{2}\right)$, peroxyacetyl radicals $\left(\mathrm{CH}_{3} \mathrm{C}(\mathrm{O}) \mathrm{O}_{2}\right)$, or both, was probable although the occurrence of $\mathrm{R} 9$ could also explain the generation of a signal. $\mathrm{CH}_{3} \mathrm{O}_{2}$ has an ambient concentration around $10^{8}$ molecules $\mathrm{cm}^{-3}$ and so could present a serious interference.

The signal from $\mathrm{CH}_{3} \mathrm{O}_{2}$ was investigated by replacing acetone with acetaldehyde or methyl iodide which both photolyse to produce methyl, but not acetyl, radicals at $254 \mathrm{~nm} . \mathrm{CH}_{3} \mathrm{O}_{2}$ is therefore the only peroxy radical produced in either system 
and the risk of $\mathrm{OH}$ production following $\mathrm{R} 9$ is removed. $\mathrm{NO}$ at $0.8 \mathrm{ppm}$ could be added downstream of the bulb to remove this $\mathrm{CH}_{3} \mathrm{O}_{2}$.

A chromatographic interference during this experiment resulted in poor integration of the 2,5-DHBA peaks. The minimum and maximum peak areas were determined for a given experimental condition to represent the range of error in the integration $(n=8-10)$. Although there is a large error associated with these results, a significant amount of qualitative information can still be obtained.

A background signal was obtained by photolysing the organic reactant in nitrogen with air being added downstream of the bulb to facilitate 2,5-DHBA production. The results are presented in Table II in the column labelled 'background signal.' When air is added to the flow of organic reactant prior to the photolysis region $\mathrm{CH}_{3} \mathrm{O}_{2}$ should be produced. These results are shown in Table II under the column labelled ' $\mathrm{CH}_{3} \mathrm{O}_{2}$ radicals produced.' The addition of NO to this system after the bulb should reduce the $\mathrm{CH}_{3} \mathrm{O}_{2}$ to $\mathrm{CH}_{3} \mathrm{O}$ via $\mathrm{R} 10$, which may further react to produce $\mathrm{CH}_{3} \mathrm{ONO}$ or other products. These results are summarised in Table II under the column titled ' $\mathrm{CH}_{3} \mathrm{O}_{2}$ radicals removed.'

$$
\mathrm{CH}_{3} \mathrm{O}_{2}+\mathrm{NO} \rightarrow \mathrm{CH}_{3} \mathrm{O}+\mathrm{NO}_{2}
$$

Table I. Mean 2,5-DHBA signal for different experimental conditions during synthesis of $\mathrm{CH}_{3} \mathrm{CO} \cdot \mathrm{O}_{2}$ and $\mathrm{PAN}$

\begin{tabular}{lcc}
\hline Conditions & UV Lamp status & $\begin{array}{c}\text { Mean 2,5-DHBA } \\
\text { signal/fmoles } \mathrm{L}_{\text {air }}^{-1}\end{array}$ \\
\hline Acetone & Off & 0.57 \\
Acetone and $\mathrm{NO}_{2}$ & Off & 2.46 \\
$\mathrm{O}_{2}$ & On & 5.04 \\
$\mathrm{O}_{2}+\mathrm{NO}_{2}$ & On & 3.99 \\
Acetone $+\mathrm{O}_{2}$ & On & 110.21 \\
Acetone $+\mathrm{O}_{2}+5 \mathrm{ppm} \mathrm{NO}_{2}$ & On & 13.91 \\
\hline
\end{tabular}

Table II. Mean 2,5-DHBA signal for different experimental conditions during synthesis of $\mathrm{CH}_{3} \mathrm{CO}_{2}$. A blank was determined by addition of $\mathrm{O}_{2}$ after the bulb. See text for further explanation

\begin{tabular}{lllll}
\hline & & \multicolumn{3}{c}{ Mean 2,5-DHBA signal/fmoles $\mathrm{L}_{\text {air }}^{-1}$} \\
\cline { 3 - 5 } Substrate & Integration used & $\begin{array}{l}\text { Background } \\
\text { signal }\end{array}$ & $\begin{array}{l}\mathrm{CH}_{3} \mathrm{O}_{2} \\
\text { radicals produced }\end{array}$ & $\begin{array}{l}\mathrm{CH}_{3} \mathrm{O}_{2} \\
\text { radicals removed }\end{array}$ \\
\hline \multirow{2}{*}{ Methyl iodide } & $\max$ & 22 & 258 & 10 \\
& $\min$ & 11 & 130 & 9.9 \\
Acetaldehyde & $\max$ & 12 & 264 & 34 \\
\multirow{2}{*}{ Acetone } & $\min$ & 3.8 & 146 & 17 \\
& $\min$ & 21 & 109 & 38 \\
\hline
\end{tabular}


A large increase in the produced 2,5-DHBA in the presence of $\mathrm{CH}_{3} \mathrm{O}_{2}$ radicals suggests that $\mathrm{CH}_{3} \mathrm{O}_{2}$ reacts with salicylic acid to produce 2,5-DHBA. Since the radicals were produced at high concentration and in the presence of UV light and oxygen, a range of secondary species could have also been produced in this experiment that could oxidise salicylic acid. Peroxides produced from the $\mathrm{CH}_{3} \mathrm{O}_{2}$ self-reaction for instance and $\mathrm{OH}$, produced from ozone and $\mathrm{HO}_{2}$ and other ways were a primary concern. A simulation of the experiment was therefore carried out using FACSIMILE software (Curtis and Sweetenham, 1987) to determine which other oxidants might be present. The model included relevant photolysis rates, gas phase reactions and physical loss processes (Ross et al., 1992; Westley et al., 1994). These results showed minimal production of $\mathrm{OH}\left(\sim 2 \times 10^{4} \mathrm{OH} \mathrm{cm}^{-3}\right)$, indicating the enhanced signal could not have been due to $\mathrm{OH} . \mathrm{CH}_{3} \mathrm{O}_{2}$ radicals were the only oxidant present in appreciable concentrations under our simulated experimental conditions and were therefore the likely oxidising species. (Salmon, 2002).

The quantitative oxidative effect of $\mathrm{CH}_{3} \mathrm{O}_{2}$ radicals was investigated by comparing experimental results with those from the simulation. The range associated with the result was high due to the uncertainty in estimating the photolysis rates inside the $1-\mathrm{L}$ bulb in the simulation and in chromatographical difficulties.

A detailed discussion of the simulation and comparison with experimental results can be found elsewhere (Salmon, 2002) but consideration of the upper and lower limits from the experiment and simulation suggest that the interference due to methylperoxy radicals could range from 6 to $2300 \mathrm{CH}_{3} \mathrm{O}_{2}$ radicals sampled per molecule of 2,5-DHBA produced. The results from acetone photolysis are not included here due to the chromatographic difficulty alluded to above. Using a central estimate of the photolysis rates results in an estimate of magnitude of the interference due to methylperoxy radicals of $9-900 \mathrm{CH}_{3} \mathrm{O}_{2}$ radicals sampled per molecule of 2,5-DHBA produced. At typical ambient concentrations of $5 \times 10^{8} \mathrm{CH}_{3} \mathrm{O}_{2}$ $\mathrm{cm}^{-3}, 6 \times 10^{5}$ to $6 \times 10^{7} 2,5$-DHBA molecules would be produced per cubic centimetre of air sampled. This signal would correspond to $\mathrm{OH}$ concentrations ranging from $2 \times 10^{6}$ to $2 \times 10^{8}$ molecules $\mathrm{cm}^{-3}$ and thus an interference of $200-20000 \%$.

Results from our ambient measurements further suggest evidence of such an interference. As before, a blank was determined by sampling through a teflon tube so that $\mathrm{OH}$ radicals would be lost to the walls. The wall loss rate for $\mathrm{OH}$ is faster than that for $\mathrm{HO}_{2}$ and $\mathrm{CH}_{3} \mathrm{O}_{2}$, which have wall loss rate constants of $2.8 \mathrm{~s}^{-1}$ and $0.8 \mathrm{~s}^{-1}$, respectively (Mihele et al., 1999). Under our sampling conditions all $\mathrm{OH}$ and $\mathrm{HO}_{2}$ radicals should be lost to the walls whereas only $\sim 32 \%$ of $\mathrm{CH}_{3} \mathrm{O}_{2}$ radicals should be lost. High blank samples were often observed, and some blank values were even larger than the 'sample' values. The blank signals observed in the field could be explained by an interference from peroxy radicals. Although this conclusion is only semiquantitative, it does indicate that methylperoxy radicals produce a significant interference in measurements on ambient air.

One possible mechanism for this interference is shown as R11. Although this reaction is exothermic in the gas phase, the activation energy required to form 
the intermediates hinders its progression under atmospheric conditions (Zhu et al., 2001). Aqueous phase interactions may however alter the energetics of the reaction. A number of complexes are formed between formaldehyde and water due to strong hydrogen bonding (Kumpf and Damewood, 1989; Tsuzuki et al., 1999; Turner et al., 2000; Chandra et al., 2000). Computations carried out by G. Koyanagi (private communication) showed that the transition state and final product enthalpies are reduced if solvation effects are taken into consideration. Although there would still be a significant activation barrier, the increased exothermicity and decreased activation barrier due to solvation should make R11 more probable in the aqueous phase than the gas phase (G. Koyanagi, private communication, 2002). A proportion of $\mathrm{CH}_{3} \mathrm{O}_{2}$ radicals could therefore decompose in the aqueous phase to produce $\mathrm{OH}$ which would react with salicylic acid to produce the interfering signal observed in both ambient and laboratory experiments.

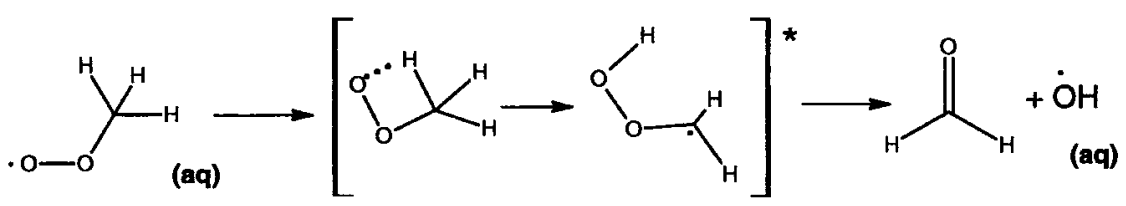

Our semi-quantitative investigations strongly suggest that $\mathrm{CH}_{3} \mathrm{O}_{2}$ oxidises salicylic acid such that ambient concentrations mask the signal due to atmospheric $\mathrm{OH}$, thus explaining the unexpectedly high signals reported in this work and by Chen 1995, Chen and Mopper, 2000, Ren et al. (2000, 2002) and the Max-PlanckInstitüt, Mainz (E. Oberlander, private communication, 1999). Discovery of the reaction with $\mathrm{CH}_{3} \mathrm{O}_{2}$ also suggests that there are many atmospheric species, and combination of species, which would have to be tested to support results on $\mathrm{OH}$ mixing ratios obtained using this technique.

\subsection{FURTHER AMBIENT AIR TESTING}

In addition to tests at York University, Toronto, the method was further field tested during the Southern Ontario Aerosol Study (SONTAS) in July 2000. Sampling occurred at a relatively clean air site situated $8 \mathrm{~km}$ north of Lake Erie and $60 \mathrm{~km}$ upwind (SW) of Hamilton. On July 7th, a clear, sunny day with little cloud cover or pollution, twelve 35-min runs were carried out between 10:41 and 19:40 local time. Table III shows experimental results from this day. Each sample or blank solution was analysed twice and the mean values were presented. The 2,5-DHBA signals obtained both in the absence and presence of $\mathrm{OH}$ were about 5 to 10 times larger than previously measured ambient $\mathrm{OH}$ concentration $\left(\sim 5 \times 10^{6} \mathrm{OH} \mathrm{cm}^{-3}\right)$.

The signal was removed if air was drawn through a solid KI scrubber prior to the reaction chamber demonstrating that the interference was not an artefact 
Table III. Ambient measurements obtained during SONTAS, 7 July 2000

\begin{tabular}{lll}
\hline Local time & $\begin{array}{l}\text { Sample measurement apparent } \\
\mathrm{OH} / 10^{7} \text { molecules } \mathrm{cm}^{-3}\end{array}$ & $\begin{array}{l}\text { Blank measurement apparent } \\
\mathrm{OH} / 10^{7} \text { molecules } \mathrm{cm}^{-3}\end{array}$ \\
\hline $10: 58$ & 2.64 & 3.96 \\
$11: 43$ & 2.81 & \\
$12: 27$ & & 5.75 \\
$13: 16$ & 5.71 & 5.83 \\
$14: 01$ & 3.39 & 4.11 \\
$14: 48$ & 4.36 & 6.46 \\
$15: 34$ & 6.41 & \\
$16: 19$ & & 5.84 \\
$17: 02$ & & 3.28 \\
$17: 49$ & 2.40 & 2.25 \\
$18: 33$ & 1.89 & 3.32 \\
$19: 22$ & 3.33 & 3.29 \\
\hline
\end{tabular}

Sampling conditions used an initial salicylic acid volume of $5 \mathrm{~mL}$ at $\mathrm{pH}=4.6$. Samples and blanks were run in parallel for $35 \mathrm{~min}$ and analysed within every $4 \mathrm{~min}$. Values given are the mean of two analyses. Local time is the middle of the sampling period.

produced during handling or analysis. Air bubbled through phosphate buffer and KI alone showed no 2,5-DHBA, ruling out the possibility that a fluorescent species with a similar retention time to 2,5-DHBA was interfering. In addition, when KI was added in quantities sufficient to remove any interference from ozone, the interference persisted, indicating that the observed interference was not due to ozone.

The magnitude of the $\mathrm{OH}$ signals obtained during this field study were similar to those reported by Chen (1995) and Ren et al. (2002). Neither of these studies, however, determined a blank signal. The interference correction used by Chen (1995) was the signal produced in a second sampler in series, which will only show the magnitude of interferences from species that have survived the first sampler and therefore does not give an accurate measure of the interference produced in the first bubbler by radicals such as $\mathrm{CH}_{3} \mathrm{O}_{2}$. Both Chen and Mopper (2000) and Ren et al. (2002) reported $\mathrm{OH}$ concentrations higher than expected and attributed this to the presence of high levels of pollutants. The data obtained during SONTAS and in our laboratory suggests that these signals are due to factors other than $\mathrm{OH}$ oxidising salicylic acid.

\section{Conclusion}

A simple, portable, and affordable method for the measurement of hydroxyl was examined. The analytical technique had a detection limit below 5 femtomoles $(50 \mathrm{pM})$ 
towards 2,5-DHBA and was about 15 times less sensitive towards 2,3-DHBA. The yield of 2,5-DHBA was found to be strongly dependent on $\mathrm{pH}$, reaching maximum values around $30 \%$ above $\mathrm{pH} 4.5$. The yield of 2,3-DHBA was relatively independent of $\mathrm{pH}$ with a maximum around $50 \%$ at $\mathrm{pH} 2.5$. These results are in agreement with Lang et al. (1996) and Jen et al. (1998) but not those presented by Chen (1995) and Chen and Mopper (2000), which report a maximum 2,5-DHBA yield around $100 \%$ at $\mathrm{pH} 7$.

Using the optimum condition in each case, detection limits for 2,3- DHBA and 2,5-DHBA of $8 \times 10^{6}$ and $9 \times 10^{5} \mathrm{OH} \mathrm{cm}^{-3}$, respectively, were obtained. 2,5DHBA was therefore the only product detectable with sufficient sensitivity for measurement of typical daytime $\mathrm{OH}$ concentrations.

We have shown that salicylic acid is readily oxidised by various processes to produce 2,5-DHBA. These processes were found to involve light, metals, bacteria, hydrogen peroxide, alkylperoxy radicals and ozone. The majority of these interferences were suppressed, but a complex system of poorly understood aqueous phase radical chemistry still occurs in the reaction solution. Discovery of the reaction between $\mathrm{CH}_{3} \mathrm{O}_{2}$ radicals and salicylic acid is of major concern since ambient concentrations of $\mathrm{CH}_{3} \mathrm{O}_{2}$ are large enough to cause an interference at least as large as the signal expected from $\mathrm{OH}$. In addition, the interference by larger peroxy radicals, degradation of reservoir species such as PAN in the solution, surface reactions occurring at the interface of the scrubbing solution and air sample or catalytic activity by metals present in small aerosols are all unquantified. Each of these could aid in the oxidation of salicylic acid to 2,5-DHBA and therefore interfere with this technique. The extremely low concentrations of hydroxyl radicals in the air, high sensitivity required by the method and complexity of the chemical systems both in the atmosphere and in solution mean that 2,5-DHBA production from salicylic acid oxidation is not sufficiently selective for quantification of ambient hydroxyl radicals. It is however conceivable that, should an advance occur that allows for sufficiently sensitive measurement of the 2,3-DHBA isomer, an atmospheric $\mathrm{OH}$ measurement method based on this approach may one day be developed.

\section{Acknowledgements}

The authors thank Alain Soltesz and Michael English for help with the branching ratio experiments, Lucy Masciello and Matthew Gibb for laboratory assistance, Xueping Gong for help with Chinese to English translations, the Centre for Research in Earth and Space Technology and the Natural Science and Engineering Research Council for funding.

\section{References}

Blandini, F., Martignoni, E., Ricotti, R., di Jeso, F., and Nappi, G., 1999: Determination of hydroxyl free radical formation in human platelets using high performance liquid chromatography with electrochemical detection, J. Chromatogr. B, 732, 213-220. 
Blitz, M., Heard, D., and Pilling, M. J., 2002: $\mathrm{OH}$ formation from $\mathrm{CH}_{3} \mathrm{CO}+\mathrm{O}_{2}$ : A convenient experimental marker for the acetyl radical, Chem. Phys. Lett, 365, 374-379.

Brune, W., Stevens, P., and Mather, J., 1995: Measuring $\mathrm{OH}$ and $\mathrm{HO}_{2}$ in the troposphere by laserinduced fluorescence at low pressure, J. Atmos. Sci. 52, 3328-3336.

Buehler, R. E., Staehlin, J., and Hoigne, J., 1984: Ozone decomposition in water studied by pulse radiolysis. 1. $\mathrm{HO}_{2} / \mathrm{O}_{2}^{-}$and $\mathrm{HO}_{3} / \mathrm{O}_{3}^{-}$as intermediates, J. Phys. Chem. 88, 2560-2564.

Buxton, G. V., Langan, J. R., and Smith, J. R. R., 1986: Aromatic hydroxylation. 8. A radiation chemical study of the oxidation of hydroxycyclohexadienyl radicals, J. Phys. Chem. 90, 6309-6313.

Campbell, M. J., Hall, B. D., Sheppard, J. C., Utley, P. L., O'Brien, R. J., Hard, T. M., and George, L. A., 1995: Intercomparison of local hydroxyl measurements by radiocarbon and FAGE techniques, J. Atmos. Sci. 52, 3421-3427.

Chandra, A. K., Nguyen, M. T., and Zeegers-Huyskens, T., 2000: Density functional calculations on simple carbonyl bases: Protonation and hydrogen bond formation with water, Chem. Phys. 255, 149-163.

Chen, X., 1995: Determination of atmospheric hydroxyl radical by liquid phase scrubbing and high performance liquid chromatography, Dissertation for Ph.D., Washington State University.

Chen, X. and Mopper, K., 2000: Determination of tropospheric hydroxyl radical by liquid phase scrubbing and HPLC: Preliminary results, J. Atmos. Chem. 36, 81-105.

Cooper, P. L. and Abbatt, J. P. D., 1996: Heterogeneous interactions of $\mathrm{OH}$ and $\mathrm{HO}_{2}$ radicals with surface characteristic of atmospheric particulate matter, J. Phys. Chem. 100, 2249-2254.

Coudray, C., Talla, M., Martin, S., Fatome, M., and Favier, A., 1995: High-perfomance liquid chromatography-electrochemical determination of salicylate hydroxylation products as an in vivo marker of oxidative stress, Anal. Biochem. 227, 101-111.

Creasey, D. J., Heard, D. E., and Lee, J. D., 2000: Absorption cross-section measurements of water vapour and oxygen at $185 \mathrm{~nm}$. Implications for the calibration of field instruments to measure $\mathrm{OH}, \mathrm{HO}_{2}$ and $\mathrm{RO}_{2}$ radicals, Geophys. Res. Lett. 27, 1651-1654.

Crosley, D. R., 1995: The measurement of $\mathrm{OH}$ and $\mathrm{HO}_{2}$ in the atmosphere, J. Atmos. Sci. 52, 3299-3313.

Curtis, A. R. and Sweetenham, P., 1987: FACSIMILE release H users manual, UK AERE report R11771; Computer Science and Systems Division, AERE Harwell, Ditcot, OXON 11ORA, UK.

Das, D. K., Cordis, G. A., Rao, P. S., Liu, X., and Maity, S., 1991: High-performance liquid chromatographic detection of hydroxylated benzoic acids as an indirect measure of hydroxyl radical in heart: Its possible link with the myocardial reperfusion injury, J. Chromatogr. 536, 273282.

Diez, L., Livertoux, M.-H., Stark, A.-A., Wellman-Rousseau, M., and Leroy, P., 2001: Highperformance liquid chromatographic assay of hydroxyl free radical using salicylic acid hydroxylation during in vitro experiments using thiols, J. Chromatogr. B 763, 185-193.

Dorn, H.-P. and Hofzumahaus, A., 2000: Measurement methods for atmospheric OH, IGACtvities Newsl. Int. Atmos. Chem. Proj. 21, 7-11.

Dupont, I., Berthou, F., Bodenez, P., Bardou, L., Guirriec, C., Staphan, N., Dreano, Y., and Lucas, D., 1999: Involvement of cytochromes P-450 2E1 and 3A4 in the Hydroxylation of salicylate in Humans, Drug Metab. Dispos., Am. Soc. Pharmacol. Exper. Ther. 27(3), 322-326.

Eisele, F. and Tanner, D., 1991: Ion-assisted tropospheric OH measurements, J. Geophys. Res. 96. 9295-9308.

Eisele, F. L., 1995: New insight and questions resulting from recent ion-assisted $\mathrm{OH}$ measurements, J. Atmos. Sci. 52, 3337-3341.

Felton, C., Sheppard, J., and Campbell, M., 1990: The radiochemical hydroxyl radical measurement method, Environ. Sci. Technol. 24(12), 1841-1847. 
Fenske, J. D., Hasson, A. S., Ho, A., and Paulson, S. E., 2000: Measurement of absolute unimolecular and bimolecular rate constants for $\mathrm{CH}_{3} \mathrm{CHOO}$ generated by the trans-2-Butene reaction with ozone in the gas phase, J. Phys. Chem. A 104, 9921-9932.

Gokoren, N. and Tunçel, M., 1997: A capillary electrophoretic method for examination of hydroxylation of salicylate ion to determine hydroxyl free radical, Pharmazie 52(9), 726-729.

Gonzalez, M. C. and Martire, D. O., 1997: Kinetics of $\mathrm{O}^{-}$and $\mathrm{O}_{3}^{-}$in alkaline aqueous solutions, Water Sci. Technol. 35(4), 49-55.

Grootveld, M. and Halliwell, B., 1986: Aromatic hydroxylation as a potential measure of hydroxylradical formation in vivo, Biochem. J. 237, 499-504.

Halliwell, B., Kaur, H., and Ingelman-Sundberg, M., 1991: Hydroxylation of salicylate as an assay for hydroxyl radicals: A cautionary note, Free Radic. Biol. Med. 10, 439-441.

Hard, T. M., O'Brien, R. J., Chan, C. Y., and Mehrabzadeh, A. A., 1984: Tropospheric free radical determination by FAGE, Environ. Sci. Technol. 18, 768-777.

Harris, G. W., Carter, W. P. L., Winer, A. M., Pitts, J. N., Platt, U., and Perner, D., 1982: Observation of nitrous acid in the Los Angeles atmosphere and the implications for the ozone precursor relationships, Environ. Sci. Technol. 16, 414-419.

Hofzumahaus, A., Brauers, T., Aschmutat, U., Brandenburger, U., Dorn, H-P., Hausmann, M., Hessling, M., Holland, F., Plass-Dülmer, C., Sedlacek, M., Weber, M., and Ehhalt, D. H., 1997: Reply to (Lanzendorf et al., 1997): Comment on: "The measurement of tropospheric OH radicals by laser-induced fluorescence spectroscopy during the POPCORN field campaign" by Hofzumahaus $e t$ al. and "Intercomparison of tropospheric $\mathrm{OH}$ radical measurements by multiple folded long.path laser absorption and laser induced fluorescence" by Brauers et al., Geophys. Res. Lett. 24(23), 3039-3040.

Ingelman-Sundberg, M., Kaur, H., Terelius, Y., Persson, J.-O., and Halliwell, B., 1991: Hydroxylation of salicylate by microsomal fractions and cytochrome P-450, Biochem. J. 276, 753-757.

Jen, J.-F., Leu, M.-F., and Yang, T. C., 1998: Determination of hydroxyl radicals in an advanced oxidation process with salicylic acid trapping and liquid chromatography, J. Chromatogr. A 796, 283-288.

Ko, Y.-W., Chiang, P.-C., Chuang, C.-L., and Chang, E.E., 2000: Kinetics of the reaction between ozone and $p$-Hydroxybenzoic acid in a semibatch reactor, Ind. Eng. Chem. Res. 39(3), 635-641.

Kumpf, R. A. and Damewood J. R. Jr., 1989: Interaction of formaldehyde with water, J. Phys Chem. 93, 4478-4486.

Lang, K., Brodilova, J., and Lunak, S., 1996: Photochemical hydroxylation of salicylic acid with hydrogen peroxide: Mechanistic study of substrate sensitized reaction, Collect. Czech. Chem. Commun. 61, 1729-1737.

Lang, K., Wagnerova, D. M., and Brodilova, J., 1994: The role of hydrogen peroxide in dioxygen induced hydroxylation of salicylic acid, Collect. Czech. Commun. 59, 2447-2453.

Lanzendorf, E. J., Hanisco, T. F., Donahue, N. M., and Wennberg, P. O., 1997: Comment on: "The measurement of tropospheric $\mathrm{OH}$ radicals by laser-induced fluorescence spectroscopy during the POPCORN field campaign" by Hofzumahaus et al. and "Intercomparison of tropospheric $\mathrm{OH}$ radical measurements by multiple folded long-path Iaser absorption and laser induced fluorescence" by Brauers et al., Geophys. Res. Lett. 24(23), 3037-3038.

Magi, L., Schweitzer, F., Pallares, C., Cherif, S., Mirabel, P., and George, C., 1997: Investigation of the uptake rate of ozone and methyl hydroperoxide by water surfaces, J. Phys. Chem. A, 101, 4943-4949.

McCabe, D. R., Maher, T. J., and Acworth, I. N., 1997: Improved method for the estimation of hydroxyl free radical levels in vivo based on liquid chromatography with electrochemical detection, $J$. Chromatogr. B, 691, 23-32.

Meyrahn, H., Helas, G., and Warneck, P., 1987: Gas Chromatographic determination of peroxyacetyl nitrate: Two convenient calibration techniques, J. Atmos. Chem. 5, 405-415. 
Mihele, C. M., Mozurkewich, M., and Hastie, D. R., 1999: Radical loss in a chain reaction of CO and NO in the presence of water: Implications for the radical amplifier and atmospheric chemistry, Int. J. Chem. Kinet. 31, 145-152.

Mokrini, A., Ousse, D., and Esplugas, S., 1997: Oxidation of aromatic compounds with uv radiation/ozone/hydrogen peroxide, Water Sci. Technol. 35(4), 95-102.

Munoz, F., Mvula, E., Braslavsky, S. E., and von Sonntag, C., 2001: Singlet dioxygen formation in ozone reactions in aqueous solution, J. Chem. Soc., Perkin Trans. 2, 1109-1116.

Munoz, F. and von Sonntag, C. 2000: Determination of fast ozone reactions in aqueous solution by competition kinetics, J. Chem. Soc., Perkin Trans. 2, 661-664.

Owen, R.W., Wimonwatwatee, T., Spiegelhalder, B., and Bartsch, H. 1996: A high performance liquid chromatography system for quantification of hydroxyl radical formation by determination of dihydroxy benzoic acids, Eur. J. Cancer Prev. 5, 233-240.

Ren, X., Shao, K., Shao, G., and Tang, X., 2001: Measurement of gas-phase OH using liquid phase scrubbing and high performance liquid chromatography, Huanjing Huaxue 20(1), 8185.

Ren, X., Shao, K., Miao, G., and Tang, X., 2000: Determination of hydroxyl radical concentration in atmosphere, Zhongguo Huanjing Kexue (China Environ. Sci.), 21(2) 115-118.

Ren, X., Wang, H., Shao, K., Miao, G., and Tang, X. 2002: Determination and characteristics of $\mathrm{OH}$ radical in urban atmosphere in Beijing, Environmental Science (Huan.Jing Ke Xue), 23(4), 24-27 (in Chinese).

Ross, A. B., Mallard, W. G., Helman, W. P., Buxton, G. V., Huie, R. E. and Neta, P., 1992: NDRL-NIST Solution Kinetics Database-Version 1, NIST standard reference data, Gaithersburg, MD.

Salmon, R. A., 2002: A radical detection technique: Examination of a method to measure atmospheric OH, Ph.D. Dissertation, York University, Toronto, Canada.

Schiller C. L., Locquiao, S., Johnson, T. J., and Harris, G. W., 2001: Atmospheric measurements of HONO by tunable diode laser spectroscopy, J. Atmos. Chem. 40, 275-293.

Schultz, M., Heitlinger, M., Mihelcic, D., and Volz-Thomas, A., 1995: Calibration source for peroxy radicals with built-in actinometry using $\mathrm{H}_{2} \mathrm{O}$ and $\mathrm{O}_{2}$ photolysis at $185 \mathrm{~nm}, J$. Geophys. Res. 100, 18811-18816.

Seinfeld, J. H. and Pandis, S. N., 1998: Atmospheric Chemistry and Physics: From Air Pollution to Climate Change, Wiley, USA.

Spanggord, R. J., Yao, C. D. Y., and Mill, T., 2000: Oxidation of aminodinitrotoluenes with ozone: Products and pathways, Environ. Sci. Technol. 34(3), 497-504.

Staehlin, J., Buehler, R. E., and Hoigne, J., 1984: Ozone decomposition in water studied by pulse radiolysis. 2. $\mathrm{OH}$ and $\mathrm{HO}_{4}$ as chain intermediates, J. Phys. Chem. 88, 2560-2564.

Staehlin, J. and Hoigne, J., 1982: Decomposition of ozone in water: Rate of initiation by hydroxide ions and hydrogen peroxide, Environ. Sci. Technol. 16(10), 676-681.

Staehlin, J. and Hoigne, J., 1985: Decomposition of ozone in water in the presence of organic solutes acting as promoters and inhibitors of radical chain reactions, Environ. Sci. Technol. 19(12), 1206-1213.

Strolin-Benedetti, M., Brogin, G., Bani, M., Oesch, F., and Hengstler, J. G., 1999: Association of cytochrome $\mathrm{P} 450$ induction with oxidative stress in vivo as evidenced by 3-hydroxylation of salicylate, Xenobiotica 29(11), 1171-1180.

Tsai, T. H., Cheng, F. C., Hung, L. C., and Chen, C. F., 1999: Measurement of hydroxyl radical in rat blood vessel by microbore liquid chromatography and electrochemical detection: An on-line microdialysis study, J. Chromatogr B, 734, 277-283.

Tsuzuki, S., Uchimaru, T., Matsumara, K., Masuhiro, M., and Tanabe, K., 1999: Effects of basis set and electron correlation on the calculated interaction energies of hydrogen bonding complexes: $\mathrm{MP} 2$ /cc-pV5Z calculations of the $\mathrm{H}_{2} \mathrm{O}-\mathrm{MeOH}, \mathrm{H}_{2} \mathrm{O}-\mathrm{Me}_{2} \mathrm{O}, \mathrm{H}_{2} \mathrm{O}-\mathrm{H}_{2} \mathrm{CO}, \mathrm{MeOH}-\mathrm{MeOH}$, and $\mathrm{HCOOH}-\mathrm{HCOOH}$ complexes, J. Chem. Phys. 110, 11906-11910. 
Turner, G. W., Johnston, R. L., and Harris, K. D. M., 2000: Systematic computational study of the geometrical dependence of deuterium quadropole interaction parameters in an $\mathrm{O}-{ }^{2} \mathrm{H} \cdot \mathrm{O}=\mathrm{C}$ hydrogen bonded system, Chem. Phys. 256, 159-168.

Weavers, L. K., Ling, F. H., and Hoffmann, M. R., 1998: Aromatic compound degradation in water using a combination of sonolysis and ozonolysis, Environ. Sci. Technol. 32, 2727-2733.

Westley, F., Herron, J. T., Cvetanovic, R. J., Hampson, R. F., and Mallard, W. G., 1994: NIST Chemical Kinetcis Database-Version 6.01, NIST standard reference data, Gaithersburg, MD.

Yoshimura, Y., Otsuka, K., Uchimaya, K., Tanaka, H., Tamura, K., Oshawa, K., and Imaeda, K., 1989: Detection of hydroxyl radicals with salicylic acid, Anal. Sci. 5, 161-164.

Zhu, R., Hsu, C-C., and Lin, M. C., 2001: Ab initio study of the $\mathrm{CH}_{3}+\mathrm{O}_{2}$ reaction: Kinetics, mechanism and product branching possibilities, J. Chem. Phys. 115, 195-203. 